\title{
Sciendo
}

\section{Sixteenth-century Mexican Monasteries and Art. An Anthropological Perspective}

\author{
MONIKA BRENIŠÍNOVÁ
}

Center for Ibero-American Studies

Charles University, Prague, Czech Republic

monika.brenisinova@ff.cuni.cz

\begin{abstract}
This paper deals with sixteenth-century Mexican monastic architecture and art. Mexican monasteries were constructed all over the territory of New Spain (1635-1821) in relation to the need to evangelize the native American populations. The article discusses the place of this architecture and art in the historiography of the history of art taking into consideration the changes of paradigms and putting particular emphasis on anthropology and its approaches. In terms of method, it is interdisciplinary and combines synchronic and diachronic perspectives.
\end{abstract}

KEY WORDS: Mexico, New Spain, sixteenth century, evangelization, native American populations, monasteries, art, interdisciplinarity, history, anthropology, synchrony and diachrony 
MONIKA BRENIŠÍNOVÁ

Sixteenth-century Mexican Monasteries and Art. An Anthropological Perspective

\section{Introduction}

This paper addresses the sixteenth-century Mexican monastic architecture and art which was built in Central Mexico (Ciudad de México, México, Morelos, Puebla, Tlaxcala, Hidalgo) by three missionary orders ${ }^{1}$ (BORGES 1992) with the aim of evangelizing the indigenous populations (GÓMEZ CANEDO 1993; GÓMEZ CANEDO 1977; KOBAYASHI 1996; WRIGHT 1998). The majority of these convents were constructed between the years 15501570 (RUBIAL GARCÍA 2002:49; KUBLER 2012:403-407). ${ }^{2}$ After 1570 the process of Christianization of natives began to be considered to have been accomplished. In consequence, the Spanish Crown ceased to support the religious clergy and initiated a process of secularization of the monasteries. Due to this fact, the monks were forced to leave their monasteries, passing them into the hands of the secular clergy, and move to remote areas like Northern Mexico (where their work was still needed).

As regards my research, I visited Mexico for the first time in 2010, when I discovered the Mexican monastic architecture and art and began to deal with it in more detail. What surprised me while reading the specialized literature was the lack of consensus about art historical terminology in authoritative works, as Rie Arimura, a Mexican art historian, pointed out in her article entitled Hacia una nueva historia del arte: desmitificación de los conceptos estilísticos del arte novohispano del siglo XVI (Towards the New History of Art: Demystification of Stylistic Concepts of the $16^{\text {th }}$ Century New Spain Art) (ARIMURA 2005:165-183).

In Mexico, the European taxonomy and approaches of history and history of art began to be implemented - in connection with the constitution of national states - from the nineteenth century. At this time, Mexican and American scholars like Manuel G. Revilla (1864-1924), Manuel Romero de Terreros (1880-1968) and Sylvester Baxter (1850-1927) introduced Mexicans to the history of what was called colonial art (BAXTER 1934; REVILLA 1893; ROMERO DE TERREROS 1922). Afterwards, their work was followed by others, namely by Mexican Manuel Toussaint (1890-1955), Spanish Diego Angulo (1901-1986) and

1 The term "missionary orders" refers to three regular orders, namely the Franciscans, Dominicans and Augustinians, to whom the task of evangelizing the aborigine populations of Mexico was entrusted. They were joined in 1566 by the Society of Jesus, which the Spanish Crown also considered a missionary order from 1568.

2 According to George Kubler, a prominent art historian and specialist in Mesoamerican art both preColumbian and colonial, in 1550 in Mexico there were only 50 convents; by 1570 there were more than 273. Antonio Rubial García, a Mexican historian, states that in 1570 there were 273. 

1965b; TOUSSAINT 1962; KUBLER 2012). Nevertheless, according to Arimura, the approach towards colonial art and architecture based on European theory and concept did not correspond to the specific American reality and led to the prioritization of documentary evidence written by Europeans over those written by natives and to the persecution of the unique cultural identity of American art and architecture. The origins of revisionist discourse date back to the 1960s, when ideas associated with positivism, Darwinism and evolutionism (e.g. the idea of artistic styles) or the introduction and use of European terms (e.g. high and low art, folk art) began to be criticized. Some authors, such as Damián Carlos Bayón, an Argentine Art critic, stress the absence of chronology as one of the major features of Latin American art in general (BAYÓN 1974:55, 174), and Gauvin Alexander Bailey, an American art historian, who mentions, in connection with the history of Latin America's art, chronological anarchy (BAILEY 2005:15-16). At present, a number of publications with a new perspective seeking for innovative methods and fields of research on colonial art (e.g. discourse analysis) have been published, including authors like Elisa Vargas Lugo (VARGAS LUGO 2005), Elena Estrada de Gerlero (ESTRADA DEL GERLERO 2011) and Gloria Espinosa Spínola (ESPINOSA SPÍNOLA 1999).

The same gap - given by neglecting the indigenous sources - can be observed in the example of classical works on conquest (CHAUNU 1969; PRESCOTT 2001), which are significantly marked by an Eurocentric gaze (i.e. they conceive the European colonization of New World as an act of spreading Western culture and civilization). On the other hand, there are works by Inga Clendinnen (CLENDINNEN 1991; CLENDINNEN 2010), an Australian historian; by James Lockhart (LOCKHART 2013), an American historian of colonial Latin America; and by Miguel León-Portilla (LEÓN-PORTILLA 2013), a prominent Mexican historian, which offer an interesting perspective on the Conquest of Mexico in pointing out the misinterpretation of natives' behavior and Post-Columbian written sources caused by Eurocentrism. Of especial interest are also interpretative works by Serge Gruzinski (GRUZINSKI 2013; GRUZINSKI 2006; GRUZINSKI 1992), a French historian and specialist in Latin America, who frequently comes with an innovative view of the themes associated with Mesoamerica and its cultures (as the title of one of his most renowned books 
MONIKA BRENIŠÍNOVÁ

Sixteenth-century Mexican Monasteries and Art. An Anthropological Perspective

- entitled La guerra de las imágenes. De Cristóbal Colón a “Blade Runner” (1492-2019) suggests). Furthermore, he prefers to work with visual resources.

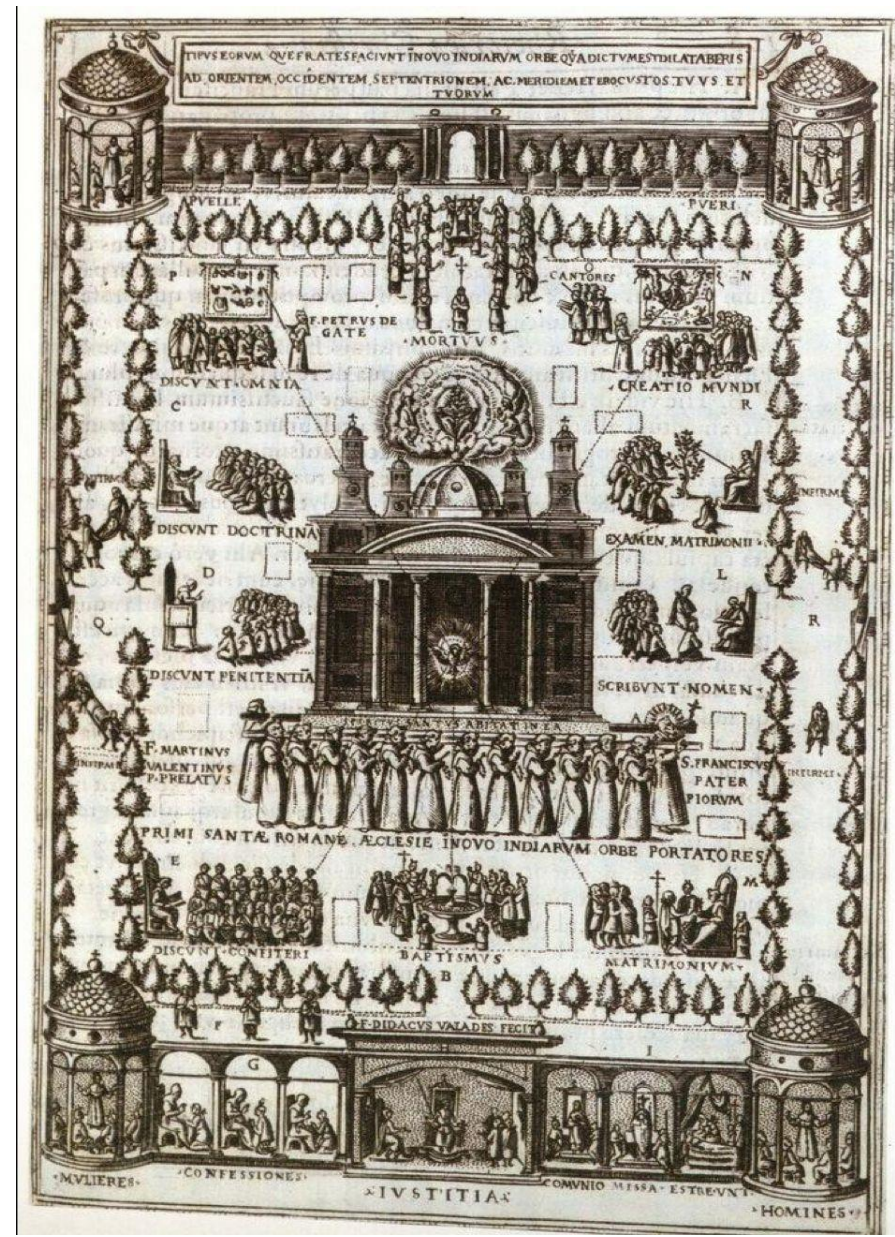

Figure 1: Atrium Sacramentorum. Diego de Valadés, "Rhetorica christiana", Perugia. Engraving, 1579. Taken from: Esteban J. Palomera, "Fray Diego Valadés, O.F.M., evangelizador humanista de la Nueva España: el hombre, su época y su obra", México, D.F., 1988. 
As a historian, I was trained to work solely with the documentary evidence deposited in archives and other institutions. The traditional category of "sources" conceived as written documents was never questioned, although many historical schools like the Annales School, History of Mentalities, Cultural History and Historical Anthropology have already pointed out a few decades ago the benefits of using other types of historical evidence, such as visual resources, instead of hand and/or typewritten documents. However, an encounter with Mexican monastic architecture and art (such as my previous university formation in humanities) together with a lack of written resources from the indigenous population of New Spain who would have kept their testimonies, made me think about the firm bond between the history and archival funds, as well as about the use of visual ones. Then, influenced by the historical schools mentioned above together with Gustaaf Renier (RENIER 1950), a British professor of Dutch History, who suggested replacing the classical historical idea of sources with that of traces (which can be any object such as manuscripts, printed books, buildings, furniture, the landscape, paintings, statues, etc.) of the past in the present, I started to focus on work with visual evidence. As Peter Burke, a British historian wrote, I am convinced that images allow historians "to share the non-verbal experiences or knowledge of past cultures" and enable them "to imagine the past in more vivid colours" (BURKE 2001:13). Further, my former education in humanities (especially in history of art and anthropology) led me to symbolic anthropology. Especially, the works written by its representatives - an American anthropologist Clifford Geertz and his British colleague Victor Turner-made me think about architecture and art as symbolic communication. In an attempt to understand what the sixteenth-century Mexican monastic architecture and its art communicated to the natives and how, I began to prefer diachronic approaches, since they allow the study of inner functions and structural relations of an era and/or a phenomenon instead of the study of their changes and developments in time. Namely, I started to work with the following anthropological notions and concepts: the Arnold van Gennep concept of rites of passage, the Turner notion of liminality together with his conception of society divided into two different modalities called structure and anti-structure or communitas, and the Geertz concepts of art as "model of reality" and "model for reality" (GEERTZ 2003:9092). 
As I have already stated, the aim of this article is to interpret Mexican monastic architecture and art from the point of view of symbolic anthropology. This architecture together with its artistic decoration was meant as one of the main tools of evangelization and as such it has been already studied by many Mexican, American and French scholars, namely the historians and art historians (BALLESTEROS GARCÍA 2000; CÓMEZ RAMOS 1989; DUVERGER 2003; ESPINOSA SPÍNOLA 1999; GÓMEZ MARTÍNEZ 1997; KUBLER 2012:289-437; MCANDREW 1965:121-597; MELI PIRALLA 2011; RUBIAL GARCÍA 2002). The artistic decoration in form of murals and sculptural reliefs was generally created by Indian artists and craftsmen in collaboration with European missionaries and as such it combines Western and Mesoamerican artistic forms and techniques. For this reason this art was labelled mestizo, tequitqui (MORENO VILLA 1986), or lately Indochristian (REYES-VALERIO 2000), and lately there has been a large discussion concerning the appropriate terminology (BAILEY 2005:79-97; ESCALANTE GONZALBO 2008). Turner's concept of liminality can be used for the study of architecture and art, as well as for understanding the sociohistorical context and its inner processes. Turner conceived liminality (TURNER 1982:2642, 52-59; TURNER 1969:95-96) as a transitional space-time that lies between two spaces or people with different social statuses. It plays a role of a threshold between the two worlds and provides a safe place for people in transitional social status. It follows, that we can conceive sixteenth-century Mexican monastic architecture as a liminal area, because it was designated to evangelize the indigenous people of Mesoamerica ${ }^{3}$ (KIRCHHOFF 1943:92107), who found themselves after the arrival of Europeans in in-between position - since they belonged neither to the pre-Colombian world of their ancestors, nor to the new colonial arrangement. Within the monastic architecture, other spaces can be conceived as liminal, especially the atrium, the entrance called portería and all types of portals and walls separating two spaces for different purposes.

An atrium ${ }^{4}$ is a space that consists of a walled courtyard, four corner chapels called posa, a monumental stone cross termed atrial located in its center and an open chapel in its front, which was usually accessible through three arched gates. It was intended solely for

3 Mesoamerica is an anthropological concept designating the region of Central America (Mexico, Guatemala, Belize, El Salvador, Nicaragua, Honduras and Costa Rica) where an array of advanced civilizations (Aztec and Maya civilizations) with common cultural elements was formed. The notion of Mesoamerica comes from the Mexican anthropologist with German origins Paul Kirchhoff, who introduced it in 1940s.

4 The term atrium comes from Spanish, atrio. Originally it was called "patio", the term "atrio" became common in the early seventeenth century. 
indigenous neophytes and catechumens, who were not allowed to enter the church. It served for doctrinal, liturgical, educational and processional activities and for other social practices like funerals (Fig. 1). The architecture and spatial organization of atriums allowed the missionaries to follow selected autochthonous traditions, such as religious processions, ritual dances called mitote or markets termed tianguis, and to preserve the outdoor form of rituals - one of the most characteristic traces of pre-Columbian religious cults. The use of selected features coming from Mesoamerican religious tradition was intentional and its aim was to facilitate the conversion of indigenous populations to the Christian faith. From the anthropological point of view, the baptisms and religious processions represent one of the most interesting activities carried out in atriums. The baptism is the crucial rite of passage in a life of Christian. Arnold van Gennep distinguished three different stages of the rites of passage: ${ }^{5}$ preliminary rites (separation), liminal rites (liminality) and postliminal rites (incorporation) (VAN GENNEP 2008). In the first stage, phase of separation, the participant of the rite is separated from the symbols and customs associated with his/her previous status in society. In the second stage, liminal phase, the participant is at limen, at a threshold; this stage is marked by depersonalization and ambiguity. Eventually, in the third stage, the incorporation phase, the participant goes through a public ritual whose objective is to present $\mathrm{him} / \mathrm{her}$ in front of the society with a new social status and reintegrate him/her into it. On the example of baptism, we can observe all these three stages of rites of passage that I have already mentioned: first, the catechumen must separate himself/herself from the world of his/her ancestors, its traditions and religion; second, he/she must undergo a catechesis-time, during which he belongs neither to the world of its ancestors, nor to the world of the Spanish newcomers; and third, after receiving baptism, he/she will become a part of the Catholic "[...] acts of especial type that suppose a certain inclination of sensibility and a certain mental orientaion [...]," (from Spanish, "[...] actos de un tipo especial que suponen una cierta inclinación de la sensibilidad y una cierta orientación mental [...].", the translation is of the author of the paper). (VAN GENNEP 2008:14). 
MONIKA BRENIŠÍNOVÁ

Sixteenth-century Mexican Monasteries and Art. An Anthropological Perspective

Church; i.e. he/she will gain a new social status, rights and obligations and will be able to incorporate into early colonial society. ${ }^{6}$

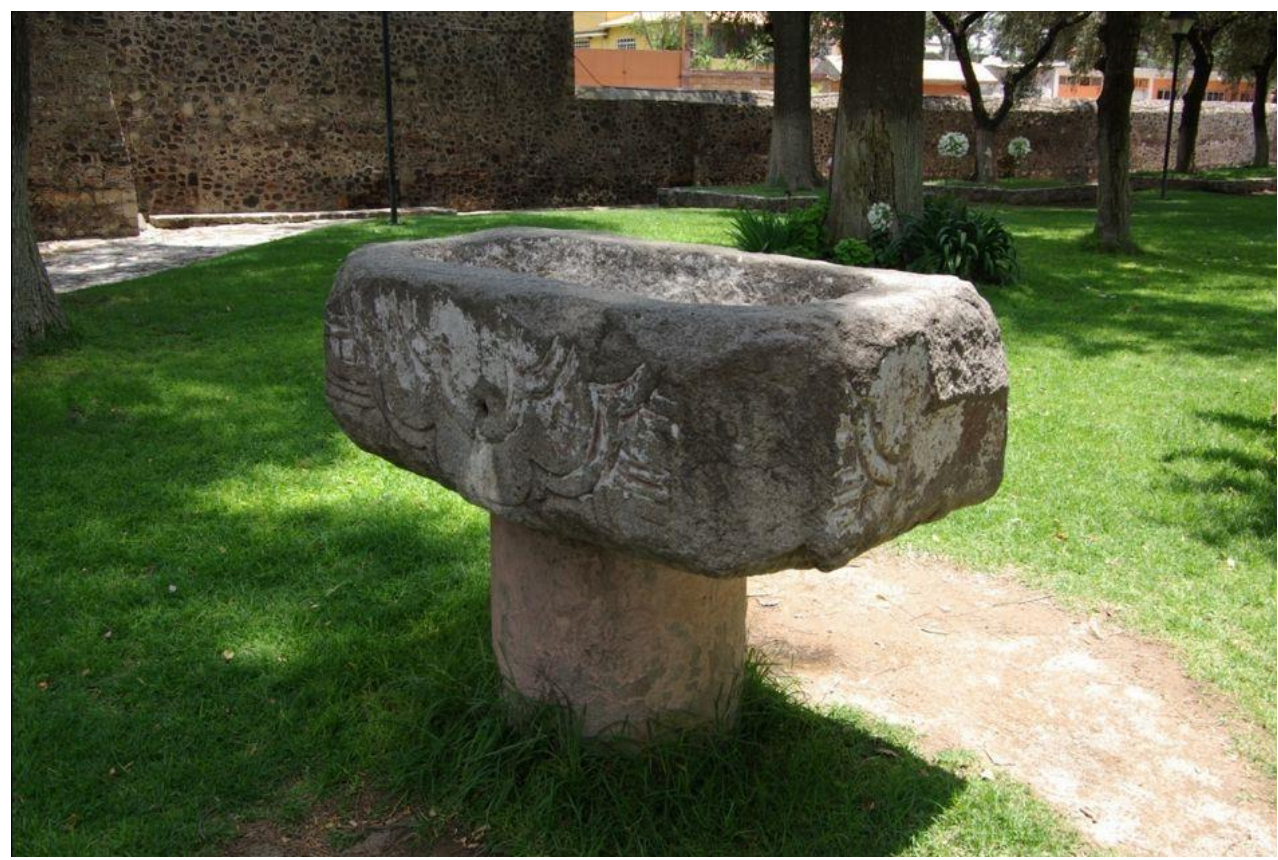

Figure 2: Baptismal font. Stone carving, $16^{\text {th }}$ century, San Juan Bautista ex-convent, Teotihuacan, México State. Photo: Daniel Pajas, 2013.

Getting back to sixteenth-century Mexico, the Franciscans, the promoters of the process of evangelization of the native population of the New Spain, carried out in the first phase of Christianization (1520-1530) mass baptisms. Unfortunately, the monumental baptismal fonts usually did not persist in their original location within the atriums (e.g. Xochitepec, Tepoztlan, Milpa Alta) and more often can be found in the interior of the churches, either in

6 Due to the fact that most mural paintings were elaborated between the 1560-1570, we cannot conceive, in my opinion, adult natives as neophytes, since the second and third generations of the indigenous population were baptized as children. 
baptismal chapels or in sotocorro ${ }^{7}$ by the entrance to the church (Oxtoticpac, Epazoyuacan, Acatzingo, Izucar, Epazoyucan, Tecali, Tecamachalco, Zinacantepec, etc.) (BRENIŠÍNOVÁ 2017:85-86) (Fig. 2).

As regards society and its organization, sixteenth-century Mexico was a dominion of Spanish Crown, with a king on one side and its people on the other. The population of the Viceroyalty of New Spain (1535-1821) was divided into two "republics": the Republic of Spaniards (from Spanish, república de epañoles) and the Republic of Indians (from Spanish, república de indios) (BERNAL et al. 2009:254, 273). The first consisted of Spaniards (born in Europe and/or in America) coming from all layers of society and was relatively culturally homogenous.

The second involved a rich variety of indigenous ethnics being linguistic and ethnic diversity its main characteristic. While the indigenous communities lived mainly in countryside and were supposed to pay tribute and provide the Spaniards with food and labor, the Spaniards resided in the cities and represented power and the sacred. This division occurred in the sixteenth-century through the quarrels between the regular clergy and the indigenous populations on one side and the secular clergy and the Spaniards on the other and it influenced the entire colonial history (e.g. such phenomena as hacienda and/or latifundism and monoculture).

In terms of anthropology, Turner discerned two different social modalities - structure and anti-structure or communitas (TURNER 1969:96-97, 125-30; TURNER 1982:44-51, 58-59). The structure is the structured and hierarchized society, where diverse social statuses can be differentiated. The anti-structure, on the other hand, is non-hierarchized society based on equality and unity. These two forms of social organization are complementary. While the presence of permanent structures is typical of structure, the existence of communitas is usually limited by time. The communitas use to emerge in liminal periods and, vice versa, the liminality conditions the formation of feelings of unity characterizing anti-structure societies. In this paper, I will conceive the Republic of Indians as communitas, while the hierarchized Republic of Spaniards will embody the structure. Of course, the given model can be applied to all components of early colonial society, including the native communities; part of a choir. 
nevertheless the main goal of this text is to capture and clarify the process of formation of sixteenth-century New Spain society.

Getting back to the religious processions, the tradition of making processions existed in both cultures - the Mesoamerican, as well as the Occidental. For example, Davíd Carrasco, a Mexican-American historian of religion, describes some of the contemporary Maya Catholic processions, in which some of the pre-Hispanic characteristics are still preserved (CARRASCO 1998:116-119, 194-201). After the arrival of Spaniards, autochthonous religious cults were banned and a set of new religious practices and beliefs related to Christianity was imposed. Among these "new" practices were Catholic processions. These were held at regular intervals in atriums and later also within the monastery, as Richard E. Phillips suggests (PHILLIPS 1999:225-250).

The processions started by gathering at the northern portal of the monastic church (in the case of Franciscans called porciúncula $)^{8}$ and continued in an anti-clockwise direction, making pauses at posa chapels. The objective of making processions (especially the direction of the movement together with themes of artistic decoration and sermons) was to introduce the indigenous people into the History of Salvation and to familiarize them with the Occidental notion of linear time (running from the Creation to the Last Judgement) (Fig. 3). The central point of Christian history was stressed by the position and decoration of atrial crosses. These were generally carved with the Instruments of the Passion (Arma Christi), and stood in the middle of atriums, and thus pointed to the redemptive role of Jesus Christ (Metepec, Alfayuacan, Calpulalpan, Tlahuelilpan, Mixcoac, Jilotepec, Tepeapulco, Mazatepec, Oxtotipac, Tlalnepantla, Tecamachalco, Tepotzotlan, Chalco, Tezontepec y Cuauhtitlan), who brought the people the possibility of Salvation and freed them from the "second death" (Fig. 4). in Italy, where the Franciscan movement began. It is also a term used for naming the plenary indulgence that the Catholic faithful can win on August 2, and in colonial Mexico is used to designate the northern portals of Franciscan monastic churches. 


\section{Sixteenth-century Mexican Monasteries and Art. An Anthropological Perspective}

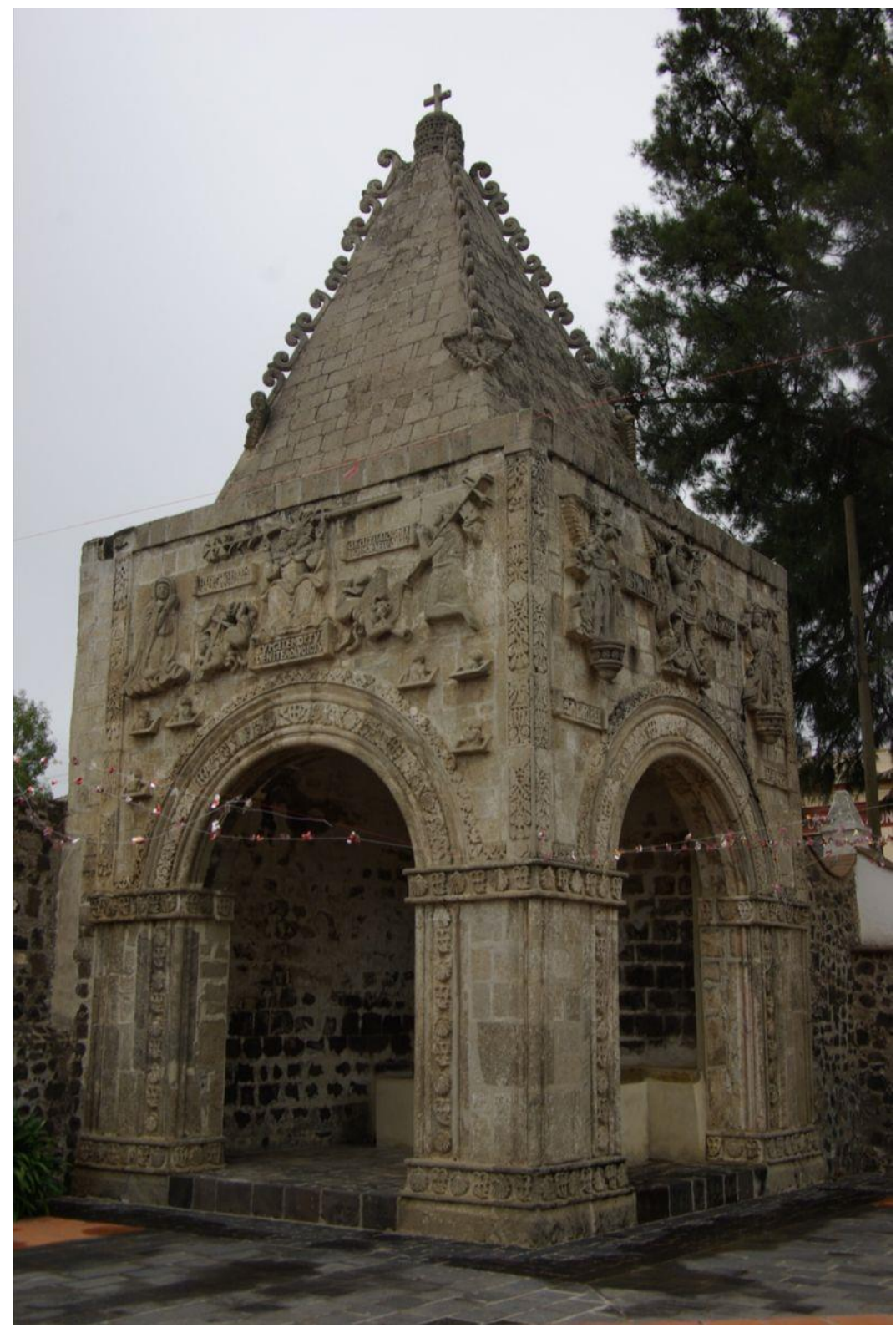

Figure 3: The posa chapel of Saint Michael the Archangel. $16^{\text {th }}$ century, San Andrés ex-convent, Calpan, Puebla State. Photo: Daniel Pajas, 2013. 
The organization of atriums with four posa chapels in the corners reflected the world view (imago mundi) of both cultures being involved, in which the world extends from a center into the four cardinal points. Moreover, this world view embodied the original organization of Nahua societies in clans called calpulli ${ }^{9}$ (GONZÁLEZ TORRES 1995:33-34), as well as the pre-Hispanic calendar system, namely the agricultural year divided between the season of rain and the season of drought, and a critical transition between them. This fact can be illustrated by an example cited by Inga Clendinnen, according to which the Franciscans organized masses and processions for rain in attempt to compete with the native gods and agricultural calendar (CLENDINNEN 2010:158). Thus the atriums have allowed the persistence of the pre-Columbian agricultural calendar, as well as some of the most important pre-Hispanic festivities (e.g. the Santa Cruz festival), related to Mesoamerican agriculture and the cultivation of its emblematic plant, corn, although in the form of Catholic holidays (BRENIŠÍNOVÁ 2017:95-101). For example, the Maya cosmos and its development over the last three centuries were studied in a collective monograph entitled Maya Cosmos, Three Thousand Years on the Shaman's Path (FRIEDEL - SCHELE - PARKER 1993.) In this book they demonstrated the connection of the church area with Mayan cosmology, its worldview, and the concepts of time and space. From the anthropological perspective, the religious processions strengthened the fellow-feeling of communitas and consolidated it.

The porterias represent another liminal space that can be distinguished within the monastic area. Generally, a portería is a vestibule in form of a vaulted structure opened by arcades to the atrial space and annexed to the western wall of the convent, which serves as an entrance to the cloister (Atlixco, Huaquechula, Huejotzingo, Epazoyucan, Actopan, Calpulalpan, Tacubaya, Coyoacan, Azcapotzalco). In some cases (when there is the furniture necessary for the Eucharist in form of an altar or even a pulpit), they served as an open chapel (Cuernavaca, Jilotepec, Tlalnepantla, Zinacantepec, Yecapixtla, Otumba). In the past, the porterías served as a threshold between the two worlds - the world of the regular clergy and the world of laymen providing a shelter for travelers and all persons who wanted to enter the cloister. ${ }^{10}$ From the anthropological point of view, the main purpose of these areas was to make possible the encounters of people with different social statuses (lay men and regular clergy, Indians and Spaniards, pagans and Catholics, rich and poor, etc.) by giving them a transitional space-time, where common social statuses lack their usual significance. With regard to the artistic decoration, the porterias were usually accompanied by a specific iconographic program stressing the role of missionary orders (and/or the Spanish Crown) within the process of the evangelization of the native American populations, which will be discussed below. 
The doorways of monastic churches - both the main ones, generally oriented towards the west, together with the north ones - represent another liminal area. In terms of Christian symbolism, the Church represents the Heavens, where the Holy Family and Saints reside, and where eternity reigns. On the contrary, the people's existence is temporary, limited by time. Thus humans are separated from eternity by death on the individual level and by the last judgement on the universal one. From the anthropological point of view, the doorways symbolize a threshold, since they separate the sacred space of the church from the profane outer space. In addition, in Western Christian tradition these spaces are frequently decorated by what are called liminal motives.

The term liminality can be applied to the study not only of architecture but also of its artistic decoration. The liminal motives represent people in liminal situations, whether it is some transitional moment of human life (e.g. baptism, marriage or death), history (e.g. Creation, Life and Death of Jesus Christ, Last Judgment) or behavior that is considered to be marginal (e.g. sin, idolatry, barbarity). The liminal motives that I will now discuss, include iconographic representations such as eschatological and apocalyptic themes (e.g. Last Judgement, Apocalypse, Woman of the Apocalypse) and themes related to death (e.g. Triumph of the Death, Dance of the Death, patron saints against death, etc.).

After 1570 the process of evangelization began to be considered accomplished as I have already mentioned above and in consequence of that, the atriums ceased to be used. It follows that there are very few examples of atriums in their original arrangement with four corner chapels (Calpan, Cholula, Huejotzingo, Tepoztlan, Epazoyuacan, Yecapixtla, Tepeji del Río, Tlaquiltenango, Tepeyanco, Atlatlahucan, Tlayacapan, Totolopan, Tochimilco, Tezontepec, Acatlan, Metztitlan), open chapel (Cholula, Actopan, Tepotztlan, Tlaxcala, Tizatlan, Tochimilco, Epazoyuacan, Alfayuacan, Atlatlahucan, Huaquechula, Tlahuelilpan, Tepeji del

$9 \quad$ The term calpulli (in Nahuatl, "large house") designates a Nahua society organization unit, which refers to a city quarter, land holding or group of craftsmen. It comes from the original clannish organization of Mesoamerican societies.

10 The Mexican monasteries served also as a public houses offering housing to guests from remote destinations. 
Río), atrial cross (see above) and original artistic decoration (in particular Calpan, Huejotzingo, Tepoztlan, Actopan).

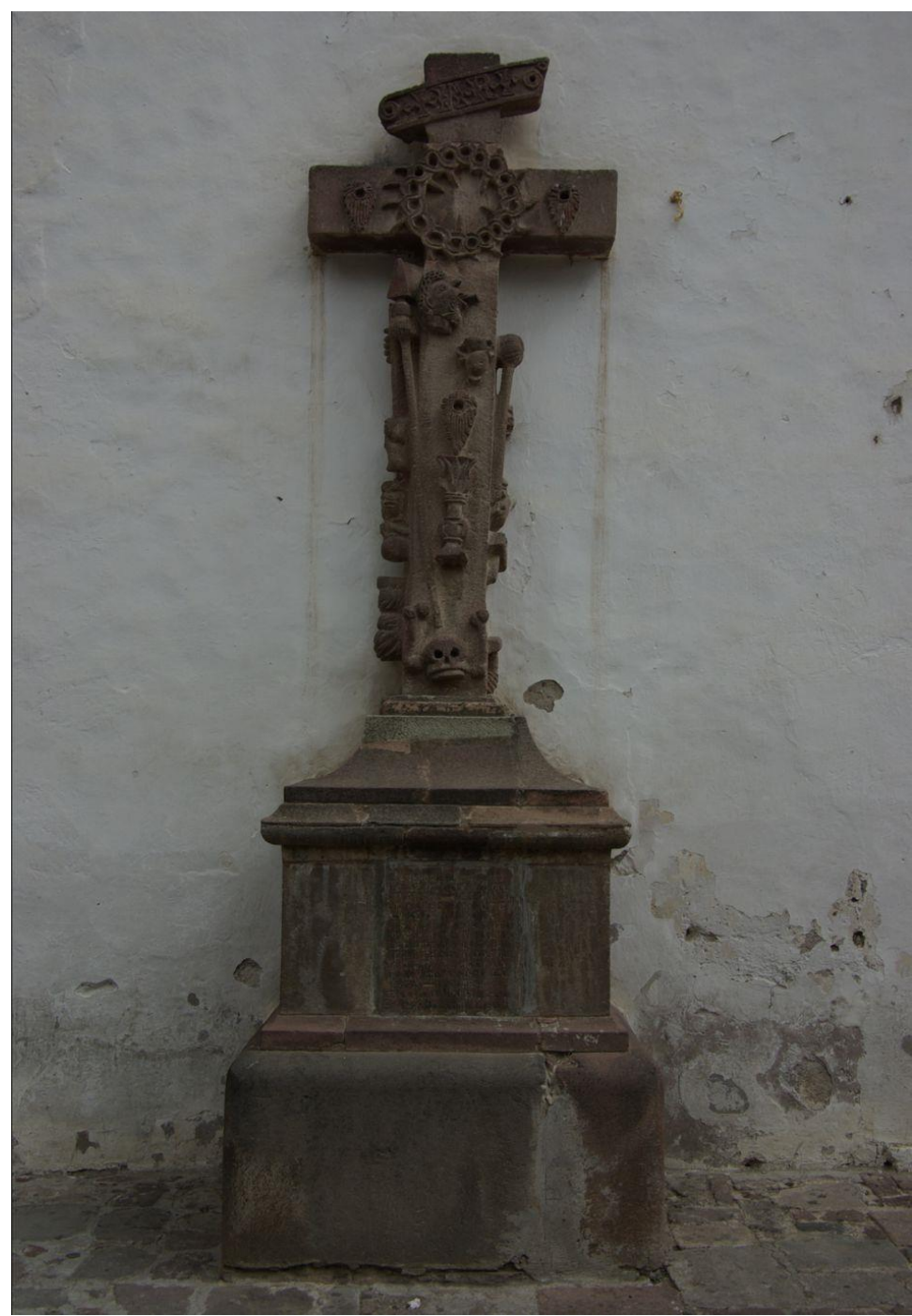

Figure 4: The atrial cross. Stone carving, $16^{\text {th }}$ century, San Francisco ex-convent, Tepeapulco, Hidalgo State. Photo: Daniel Pajas, 2013. 
Despite the fact that the low number of atriums conserved in their original appearance along with their sculptural decoration does not allow one to make certain judgments, on the basis of a comparative study of iconographic programs represented within the sixteenth-century Mexican monasteries (Actopan, Cuitzeo, Calpan, Huaqechula, Ixmiquilpan, Acolman) and visita chapels (Santa María Xoxoteco, Tizatlan) along with the documentary evidence from the sixteenth century - solely in form of the theatre of evangelization (ARACIL VARÓN 1999; ARRÓNIZ BÁEZ 1979; PARTIDA 1992; STEN - GARCÍA - ORTIZ BULLÉ GOYRI 2000 $)^{11}$ - it seems very likely that the missionary orders stressed the apocalyptic and eschatological motives in their endeavor to evangelize the indigenous populations, since the Last Judgement is the unique iconographic depiction of Western Christian artistic tradition that represents a universal picture of the world, its categories and organization (ESTRADA GERLERO 1978; SCHUESSLER 2014:150-151).

For illustration, let us have a look at the Augustinian ex-monastery of San Nicolás Tolentino in Actopan in the Hidalgo State and at its open chapel where the original iconographic program in form of polychromatic murals has been preserved. This open chapel is the largest open chapel in Mexico and the most frequently studied and mentioned (Fig. 5). The front wall of the open chapels is decorated with scenes of the Last Judgment and the Creation cycle, while the side walls are equipped with the images of Hell and eternal punishments. The scene of the Last Judgement creates a dramatic atmosphere of the approaching end of world and time, while the images of Creation Cycle and Hell show the natives the causes and consequences of the original sin for humanity. These iconographic programs stress the Salvation and show that Jesus Christ is the unique tool by which one may enter Heaven and receive eternal life (John 10:7-9). So the representations of the Lust Judgements on portals and frontal walls aimed to stress the necessity to receive baptism and hence Christianity and make possible the transition between the spaces of different statuses and purposes like church and outer space (Huaquechula), open chapel and atrium (Actopan, Santa María Xoxoteco, Cuitzeo, Tizatlan) or can be used within the processions (Ixmiquilpan, Acolman). In terms of American anthropologist $\mathrm{Cl}$. Geertz, the iconographic program of atriums showed the natives the "model of reality", i.e. how the Occidental world is organized and the "model for reality" (GEERTZ 2003:91-92), and how to live in it. In brief, the representations of the Last Judgment represent Occidental society as hierarchized and subordinated to a supreme authority in form of God (on Earth embodied by a king and authorities), where the forces of

11 For example, the first known preserved play, authored by Padre de Olmos, is called Auto del Juicio Final (Last Judgment). 
Sixteenth-century Mexican Monasteries and Art. An Anthropological Perspective

good and evil struggle for a human soul, the Christian faith being a unique path both for the earthly destiny of man (the incorporation in the structured society), and for his posthumous destiny (Salvation).

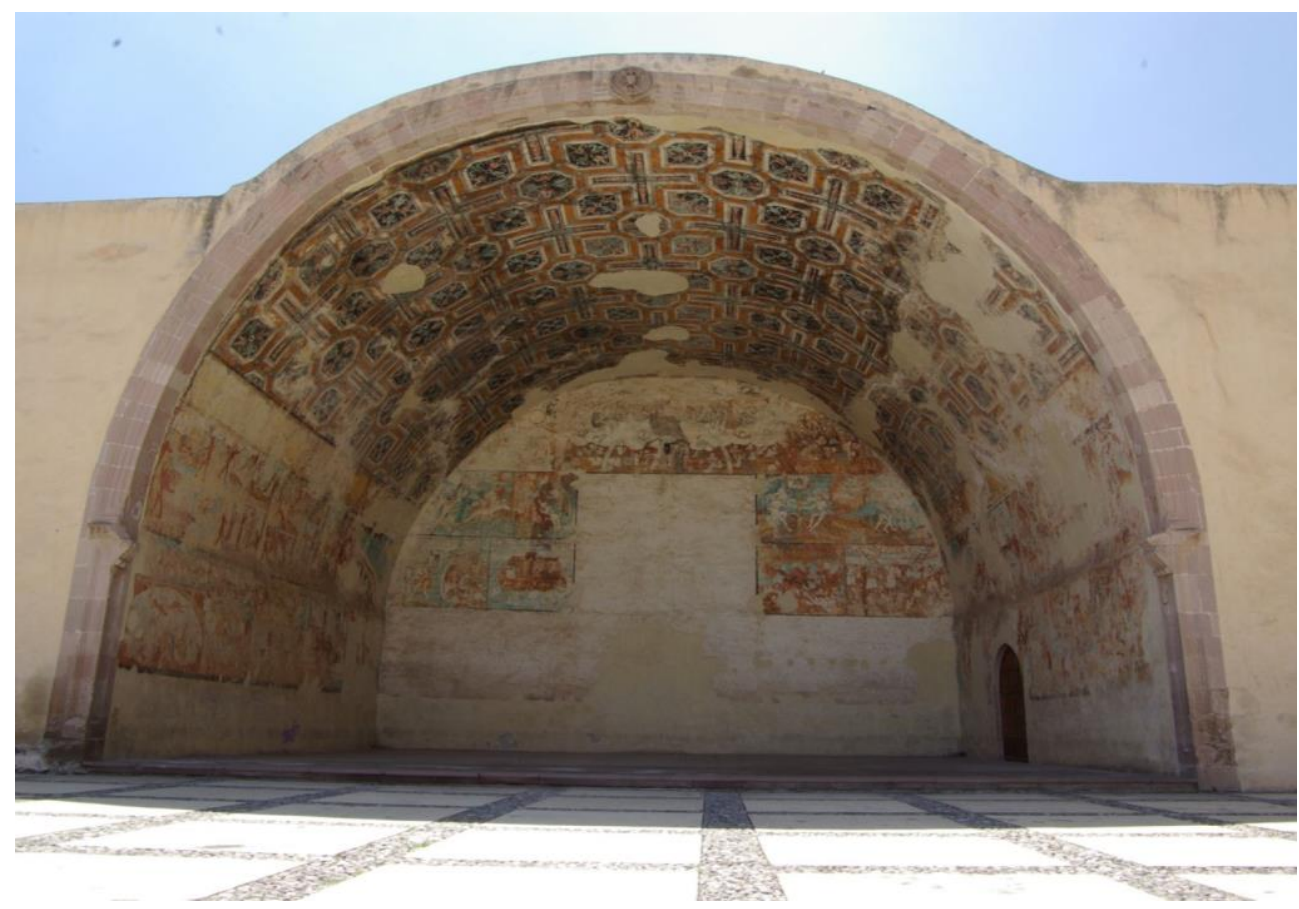

Figure 5: The open chapel. $16^{\text {th }}$ century, San Nicolás de Tolentino ex-convent. Actopan, Hidalgo State. Photo: Daniel Pajas, 2010.

Concerning the iconographic representations of Death in the sixteenth-century Mexican monastic art only two examples can be found as far as I know - one mural in Augustinian Divino Salvador ex-monastery in Malinalco in the Estado de México State and the second one in Franciscan Santa María de los Reyes ex-monastery in Huatlatlauca in the Puebla State. The first one is a monochromatic mural painting with the local use of sienna depicting the Dance of the Death (BRENIŠÍNOVÁ 2017:162, 163). It is located in a niche embedded in the northern wall separating the area of the cloister and the monastery church. This niche served as a confessional. The representation portrays a monk and Death and it served as memento mori reminding the penitents of the need to purify themselves from their sins before the last hour comes. The second case is represented by a polychromatic mural in Augustinian 
Sixteenth-century Mexican Monasteries and Art. An Anthropological Perspective

ex-convent of Santa María de los Reyes in Huatlatlauca in the Puebla State, which depicts the Triumph of Death (Fig. 6). This painting is particularly interesting, because it represents the sixteenth-century New Spain society - as first we catch sight of the Indians, then the regular clergy (nuns and monks) and eventually a group of representatives of secular clergy and Viceroyalty of New Spain - threatened by Death represented as an archer with a bow in one hand, an arrow in the other and a quiver with arrows on his back (BRENIŠÍNOVÁ 2017:162-164). This representation allows us to unveil the way the missionaries perceived and conceived the early colonial society. While the members of the Republic of Indians are anonymous and represented in a standardized way (as well as the regular clergy), the Republic of Spaniards is portrayed as hierarchized since its representatives are depicted with the signs of their social position. Hence we can recognize the viceroy Martín Enríquez (15101583) and Pope Pius V (1504-1572). From the anthropological point of view, we can say that while in the case of the Republic of Indians the communitarian character based on equality is stressed, in the case of the Republic of Spaniards structure and hierarchy (state and ecclesiastical authorities) are highlighted.

A further example of liminal motives is represented by the paintings of patron saints against death like Saint Christopher (Tlatelolco, Xochimilco, Tlaxcala and Oxtotipac), who offered a protection to travelers and against sudden death (mors improvisa or repentina). Generally, he was depicted as a giant man with a small Jesus on his shoulder and a baton in one hand while crossing a river, as we can observe in the San Bernardino de Siena convent in Xochimilco or in the Santiago convent in Tlatelolco, both Franciscan ex-monasteries situated in the capital (Fig. 7). The anthropological significance of these paintings is the same as in the case of the representations of Death and the Last Judgment that we have just seen. It is significant that all these images are located on the northern walls, a direction which was related to the religious instruction of catechumens and neophytes in the Western tradition and which was associated with the drought and hence also with death and Mictlan, the Nahua underworld in Mesoamerican practice (FERNÁNDEZ 2000:142-144; MATOS MOCTEZUMA 2010:101-107; SPRANZ 1993:262-285 - VAILLANT 1965:179). So the location of these liminal motives corresponds not only to the Occidental, but also to the 


\section{Sixteenth-century Mexican Monasteries and Art. An Anthropological Perspective}

Mesoamerican world view and testifies to the effort of missionaries to communicate their messages by symbolic forms which would be comprehensible for the indigenous populations.

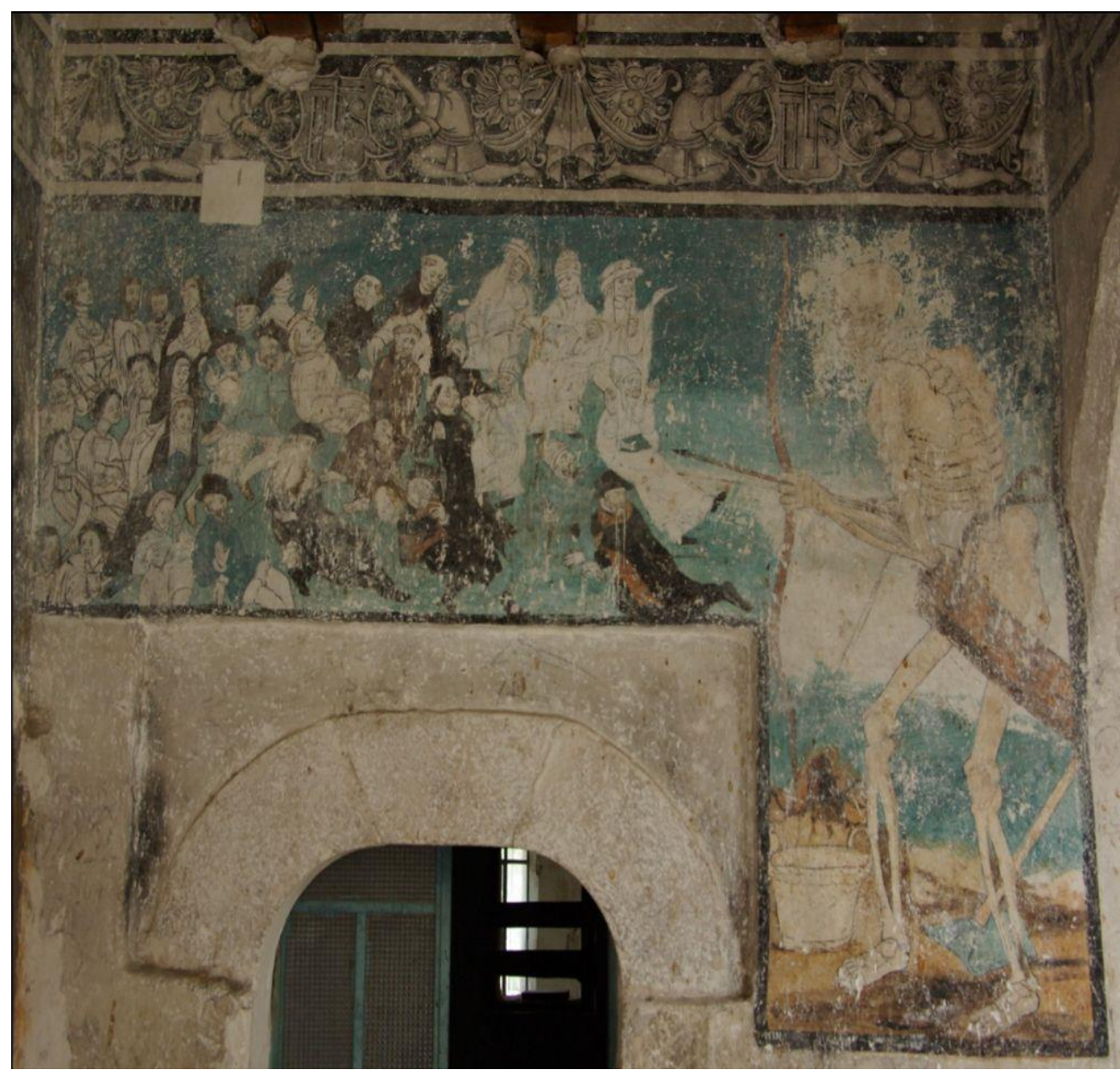

Figure 6: The Triumph of the Death. A fresco secco wall painting, $16^{\text {th }}$ century, cloister, Santa María de los Reyes ex-convent, Huatlatlauca, Puebla State. Photo: Daniel Pajas, 2013. 
Another useful concept in the study and analysis of Mexican monastic art is the system of binary oppositions (TURNER 1969:106-107). This concept stems from classical structuralism, according to which signs gain their meaning from their relationships and contrasts with other signs. Analyzing sixteenth-century Mexican monastic art, several sets of binary oppositions can be discerned such as life and death, virtues and vices, and Christianity and paganism. This system aims to structure the human behavior by presenting the dominant worldview and its cultural categories and values.

As an example, let's take the binary opposition between virtues and vices as they were recognized by the Catholic Church. The concept of holy virtues (chastity, temperance, charity, diligence, patience, kindness, and humility), whose practice should protect one against the temptations of the seven deadly sins (lust, gluttony, greed, sloth, wrath, envy, pride), became significantly popular in the Middle Ages and forms an integral part of the catechism, so it is not surprising that it was used also for the religious instructions of Indians (HACKEL 2005:147). Some of the themes related to the Christian concept of virtues and vices are displayed in the open chapel of the ex-monastery in Actopan mentioned above, as well as in the nearby small church Santa María Xoxoteco, a former visita chapel. Both are former Augustinian missions situated in the Hidalgo State and provided with the same iconographic program (BRENIŠÍNOVÁ 2017:142-145; ESTRADA GERLERO 1978:271275; VERGARA HERNÁNDEZ 2008:184-187). The scenes that are of interest to me form part of the Hell paintings decorating the side walls. Despite the fact that there is no consensus among historians of art regarding the iconographic topic of murals being discussed (most frequently it is supposed that they represent the Genre scenes or the Seven Deadly Sins) ${ }^{12}$, the important thing for my interpretation is that they display human behavior (both of Spaniards and Indians) as it was seen by missionaries. There are six Actopan scenes, but they are so deteriorated that their study is possible only due to the existence of the similar iconographic program of Santa María Xoxoteco church (ARTIGAS 1979; BALLESTEROS GARCÍA 1999). Here we observe five scenes, framed by a black line, which display from

12 The murals in Santa María church in Xoxoteco were discovered in the 1970s by Juan Benito Artigas, a naturalized Mexican architect and academic.

DOI: 10.2478/eas-2018-0011 @ University of SS. Cyril and Methodius in Trnava. All rights reserved. 
MONIKA BRENIŠÍNOVÁ

Sixteenth-century Mexican Monasteries and Art. An Anthropological Perspective

the right to the left the following motifs: Pulque drinking scene, Spanking (from Spanish, azotes), Idolatry (Fig. 8), Marriage and Lust.

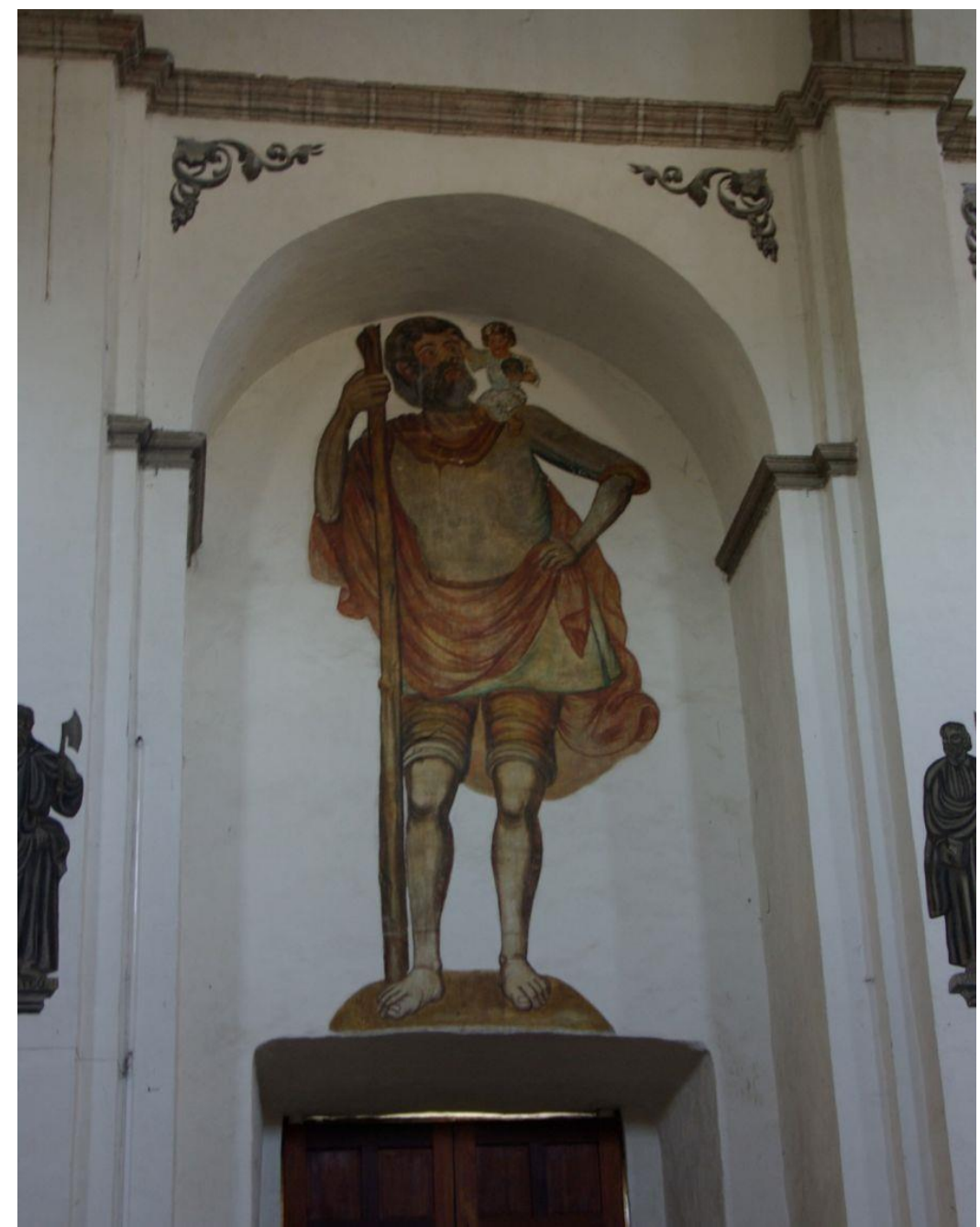

Figure 7: Saint Christopher. A fresco secco wall painting, $16^{\text {th }}$ century, monastery church, San Bernardino de Siena ex-convent, Xochimilco, México, D.F. Photo: Daniel Pajas, 2013. 
The first scene represents the natives drinking pulque, a traditional Mesoamerican beverage made from fermented maguey juice, originally called in nahuatl octli. In the painting we see a triad of Indians - a sitting couple drinking from their cups and a standing servant attending them - along with an equal number of demons prompting them to drink the alcohol, and the objects used for the consumption of pulque. In the background we observe the Mexican landscape. From the point of view of Christianity, the consumption of alcohol represents one of the seven deadly sins - gluttony. And according to Catholic doctrine committing a mortal sin without doing a proper penance leads directly to the hell (which corresponds to the location of the pictures). It turns out that the significance of this image is moralizing and the missionaries wanted to demonize the natives' behavior and discourage them from opening themselves to the Satan and forces of evil. After the conquest, the traditional indigenous world, as well as the structure of its society disintegrated. The strict norms of behavior that had dominated in the Mexican state disappeared (LOCKHART 2013:165) ${ }^{13}$ and the Indians found themselves in a transitional period without clearly defined norms, rights and obligations. After the arrival of Spaniards, many natives, forced to survive, tried to adapt to the new conditions and ways of life of the structured society, becoming alcoholics, as Sonia Corcuera de Mancera asserts in her monograph El fraile, indio y pulque (CORCUERA DE MANCERA 1997). Despite the efforts of the friars, the problem with alcoholism became one of the most serious problems of indigenous communities in the colonial era. ${ }^{14}$ Moreover, Serge Gruzinski suggests that the New Spain Church faced alcoholism only at the moral level through the posthumous infernal penalties and the doctrine of sin based on concepts such as

13 Before the arrival of Spaniards, the consumption of alcohol was subordinated to a series of rules. At least among the Nahua communities, alcohol was used during the religious rituals and as an offering for the gods. Drunkenness was considered a sacred state and the free consumption of alcoholic beverages was allowed only to priests, rulers or elders (older than 70 years) who had already fulfilled all their obligations towards the society. On the other hand, James Lockhart, is convinced that the hypotheses about the explosion of alcoholism among indigenous people after the Spanish conquest is wrong and he states that the natives were accustomed to drink alcoholic beverages, namely pulque, before the conquest. (LOCKHART 2013:165).

14 E.g. the religious processions, so popular among the natives, frequently ended in true ritual drunkenness. 


\section{Sixteenth-century Mexican Monasteries and Art. An Anthropological Perspective}

subjectivity and/or free will, which were new for natives and hence difficult to understand and internalize (GRUZINSKI 2013:205).

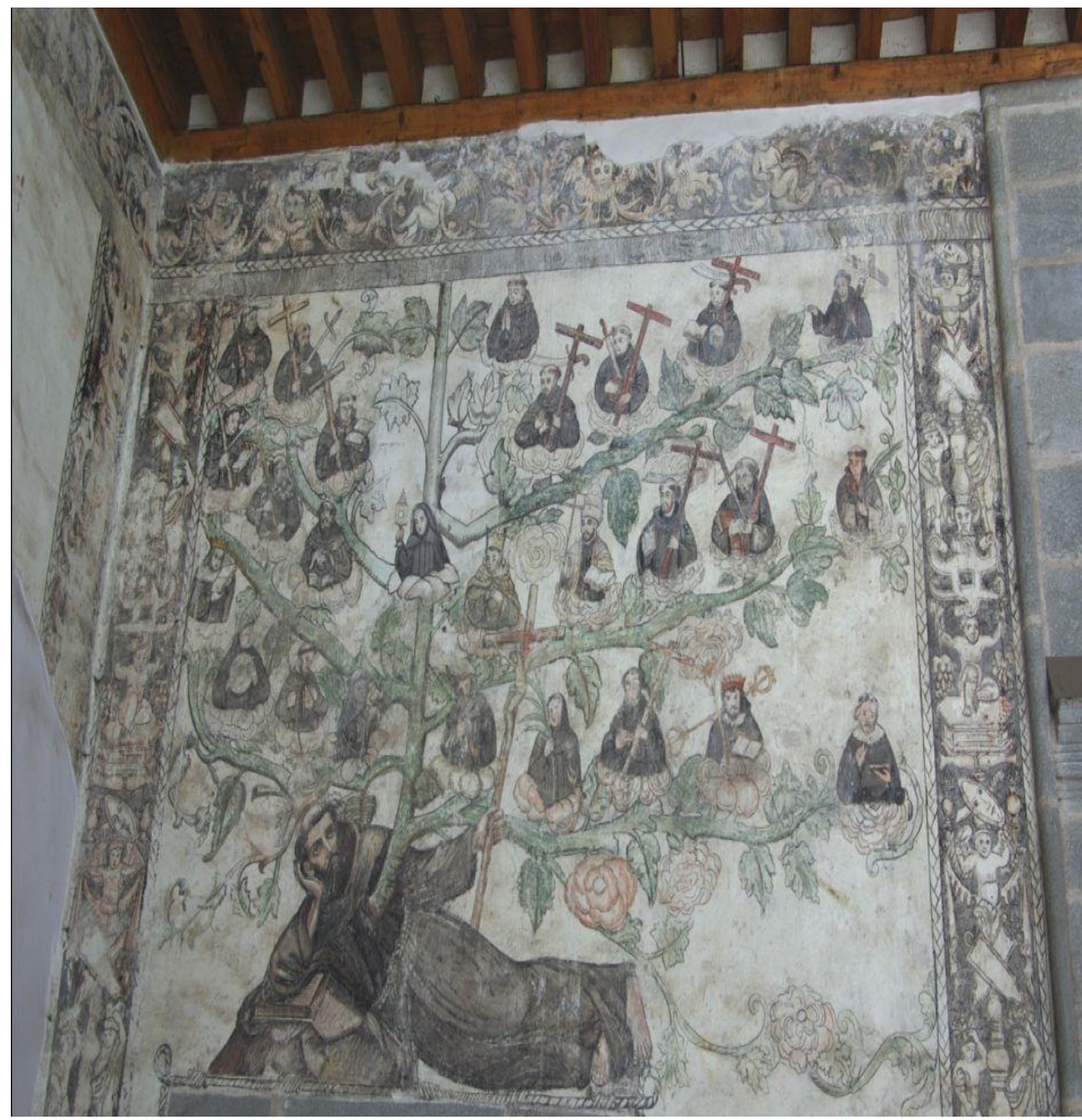

Figure 8: Idolatry (a detail from the Hell scene). A fresco secco wall painting, $16^{\text {th }}$ century, Santa María de la Purísima church, Xoxoteco, Hidalgo State. Photo: Daniel Pajas, 2013. 
The second scene represents a Spaniard spanking a native. The painting consists of two scenes. In the first one, we see two figures - a native kneeling by a Spaniard - who holds the unfortunate native by his hair and is beating him with a stick. In the second, a devil, who is fighting for the soul of the poor native with the Spanish man, joins them. The scene represents earthly castigations. The use of violence in form of physical punishments towards the natives was a common practice not only in pre-Hispanic Mexico (GIBSON 2012:119-120), ${ }^{15}$ but also in the colonial period, as shown, for example, by the good life handbooks called

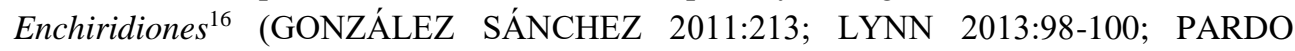
2004:118). These manuals were very popular among Spaniards and recommended the use of violence as a legitimate device in the struggle between the forces of good and evil. From the anthropological perspective, the use of physical force was conceived as a tool of incorporation of natives into the structured society aiming to change their behavior and adapt it to Occidental norms. Thus this depiction should legitimize the violent behavior of the structured society in the eyes of indigenous communities pointing to the sacred mission of the salvation of natives' souls. The way the scene is represented, depicting the standing master holding his kneeling subject by the hair on the top of his head, corresponds to both traditions, and it would be interesting to consider in future the universal comprehensibility of this motif and its depiction.

The third scene, and the first on the opposite side wall, represents idolatry. In the middle of the scene, a teocalli (i.e. a pre-Columbian temple pyramid ${ }^{17}$ ) (GENDROP 1977:160, 197) appears with two idolaters on one side and a Christianized Indian together with a Spaniard on the other. This mural is particularly interesting, as it is likely to display a Nahua category for sin called nepantla. ${ }^{18}$ This category, unlike the Christian one, lacks moral content, since it refers simply to the liminal space (the space between two worlds), a transitional, changing situation or behavior that does not fit in any known category (TORRE 2009:85; WILCOX

15 According to Charles Gibson the beating for the absence at catechism or at the mass was prohibited already in 1539. Albeit this practice persisted throughout the sixteenth century. (GIBSON 2012:119-120).

16 The manuals called Enchiridiones like Camino al cielo (The Path to Heaven) were distributed among the Spaniards by missionaries and authorities. They warned the Spaniards of the constant danger that threatened man (especially the natives) from the devil. And they reminded them that their sacred obligation was to convert sinners to the Christian faith and to teach them the Christian virtues.

17 The term temple pyramid is typical of Mesaomerican art and architecture and designates a pyramid in the form of a stepped pyramid with a small shrine on the top.

18 The term nepantla means in the Nahuatl language "in the middle, or the middle places". 
2013:249). As we can read in Historia de las Indias de Nueva España e Tierra Firme (c. 1581) by Diego Durán, a Dominican friar and missionary, where an Indian explains his bad behavior by following words:

"we are still nepantla" [...] what does it mean? to be in the middle? [...] He told me that, I should not be astonished, that since they were still not well rooted in the faith; they were still neutral, that they did not turn properly nor to the one law, neither to the other, or more precisely, that they believed in God and that at the same time they turned to their old costumes and rites of the devil, and by that he wanted to say on his abominable excuse that they are still in the middle and were neutral."19 (DURÁN 1967:237).

This category was represented in art by fur, or by blurred contours in the way, as we can observe here. Before the arrival of Spaniards, the Nahua indigenous communities believed that the afterlife was determined by the way of death. The Christian category of sin reversed this outlook, when the afterlife of man began to be conditioned by the way of life. That does not mean, in any case, that the pre-Columbian societies would lack norms and morality, but they used to associate them with the effort to maintain a balance with the supernatural forces and gods. Nevertheless, it turns out that the natives could and did have difficulties with the understanding (and hence also the internalization) of the Christian category of sin, its moral dimension along with the causes and consequences for life after death.

The fourth scene represents marriage. There are four figures - two men and two women with a landscape in the background. In the center of the representation is a Spanish couple holding hands. Unfortunately, the image of the native couple has deteriorated. As in the case of pulque drinking, the persons represented are tempted by demons trying to dissuade them from marriage and thus to deviate from the right path to Salvation.

The Catholic Church considers matrimony one of the seven sacraments (baptism, confirmation, eucharist, penance, holy orders, matrimony, extreme unction), a sign of God's presence and a means of his grace. Monogamous matrimony represents, according to the Catholic Church, the prototype of a relationship between man and woman which is based on the model of Adam and Eve, the original ancestors of all humans. After the conquest, the

19 Translation by the author. The original text reads as follows: "todavía estamos nepantla" [...] que quiere decir? estar en medio? [...] Me dijo que, como no estaban aún arraigados en la fe, que no me espantase; de manera que aún estamos neutros, que ni bien acudían a la una ley, ni a la otra, o por mejor decir, que creían en Dios y que juntamente acudían a sus costumbres antiguas y ritos del demonio, y esto quiso decir aquel en su abominable excusa de que aún permanecían en medio y eran neutros." (DURÁN 1967:237). 
Europeans began to dismantle the traditional structure of the pre-Hispanic indigenous societies based on altepetl, calpulli, extended family and a complex system of religious ideas and beliefs by prohibiting the pre-Hispanic religious cults and imposing new structures such as city councils, confraternities, the Catholic faith and a nuclear family based on monogamy. Before the arrival of Spaniards, polygamy was - especially among the nobles - a common part of natives' life. From the anthropological perspective, marriage represents one of the rites of passage par excellence, which usually introduces a married couple into adulthood, establishes new relations between them and society and thus helps to consolidate it. So after the conquest, the only right and legal way to found a family was via marriage in the Catholic Church. The fact that the Catholic Church along with Spanish authorities took hold of the institution of marriage (among others) speaks volumes about the way in which the European colonizers together with missionaries imposed on the indigenous communities the structure of Western society in form of institutions such as monogamous matrimony. Albeit the presence of the demon in this painting suggests that the natives were not always obedient and searched for ways to avoid this institution (GRUZINSKI 2013:265; LOCKHART 2013:163, 293). ${ }^{20}$

The theme of the last, fifth, scene is probably greed, which is, according to Christian doctrine, one of the seven deadly sins. An open chest, full of gold ducats and surrounded by an Indian and three demonic figures is a central motif of the scene. Unfortunately, the scene is so deteriorated that it complicates the exact identification of the actors' activity. However, I am convinced that they are fighting over the money and/or are counting it. The aim of this representation was moralizing and salvific. In addition, taking into consideration the changing situation of the regular clergy in the last third of the sixteenth century (the secularization of Mexican missions and the loss of the support of the authorities), we can also consider the intentional effort of Augustinians to gain part of indigenous financial means to legalize their illegal and/or polygamous relationships (or relationships considered immoral from the point of view of Western society and the Catholic Church such as premarital cohabitation, an incestuous relationship or a marriage contracted between non-single spouses), for example by contracting several marriages in several parishes (GRUZINSKI 2013:265). 
Sixteenth-century Mexican Monasteries and Art. An Anthropological Perspective

(e.g. donations, inheritances and indulgences) in exchange for Salvation pointing to the fatality of the accumulation of tangible property within the Christian system of values.

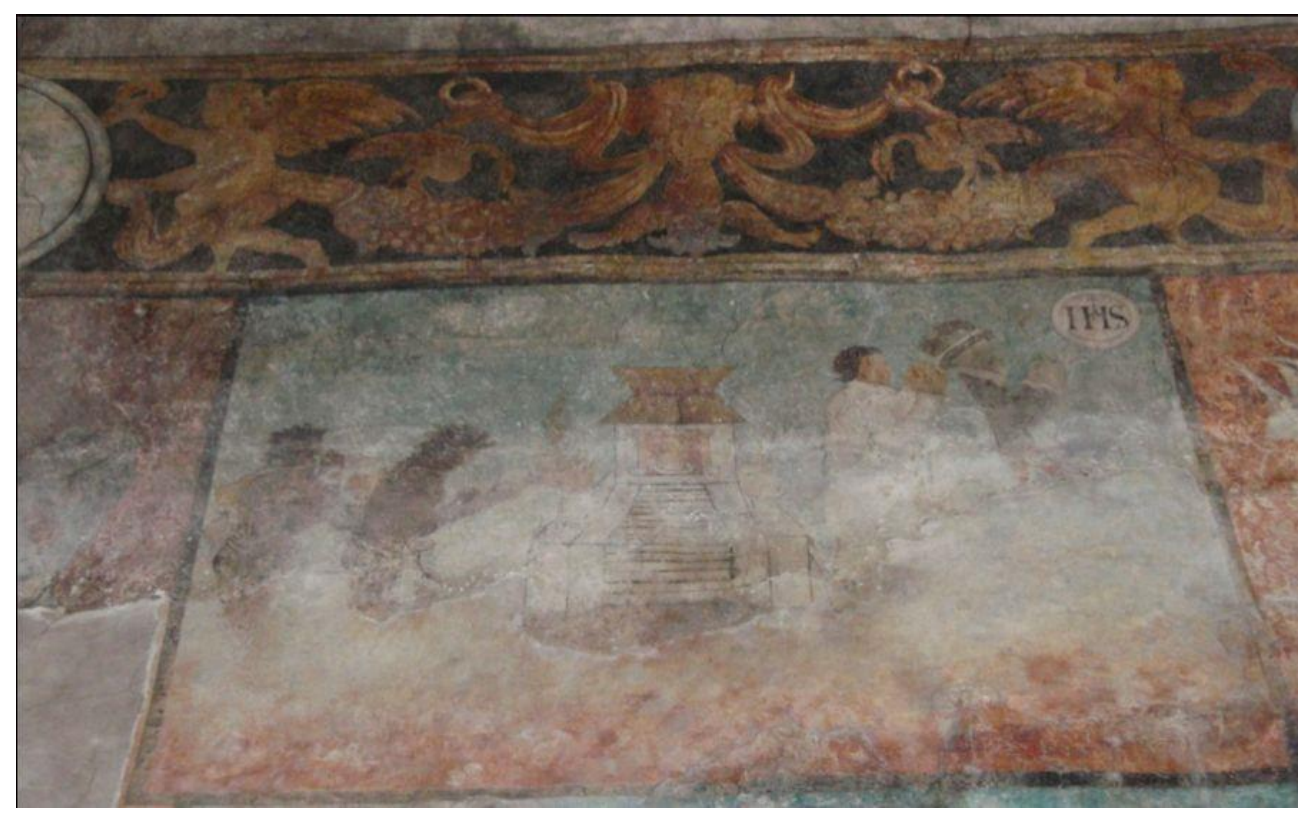

Figure 9: El Árbol genealógico de San Francisco. A fresco secco wall painting, $16^{\text {th }}$ century, portería, San Arcángel Miguel ex-convent, Zinacantepec, México. Photo: Daniel Pajas, 2013.

The last interesting example of liminal motives discussed in this article is represented by the monumental murals depicting the genealogical trees of missionary orders (Zinacantepec, Atlatlahuacan) (BRENIŠÍNOVÁ 2017:151-152). Although these mural paintings have their European roots, solely in the form of illuminations of medieval manuscripts, ${ }^{21}$ in sixteenthcentury New Spain they developed into a new monumental form. As an example, let us take

21 Examples of the genealogical trees of the mendicant orders have been preserved, for example, in the Musée Condé de Chantilly in France, where the San Benito genealogical tree from 1431 (ms. XIX B1, fol. 126) can be seen. 
the genealogical tree of Franciscan Order, which is represented in the form of a branched tree growing from the chest of Saint Francis of Assisi, the founder of the Third Order (Fig. 9).

The mural is located in the doorway of St. Archangel Michael ex-monastery in Zinacantepec in the Estado de México State. It is polychromatic and decorates the front wall, which is oriented towards the Orient. In ancient Mexico, the priests had great responsibility and this not only in regard to religion and ritual, but also in regard to education and therefore also the rules of human behavior and morals. Moreover, these were perceived as one of the means which served to keep society in harmony with supernatural forces. In my opinion, this type of painting shows the missionaries as the backbone of the newly formed society based on Christian ideas and categories. Nevertheless, other scholars, such as Louise M. Burkhart, associate these paintings with a specific pre-Columbian Nahua vision of paradise filled with flowers and trees (BURKHART 1992:91). This type of mural is firmly bound to the transitional space of the porterías mentioned above and its iconography emphasizes the foundational and salvific role of missionary orders within the early colonial society of the New Spain.

\section{Conclusion}

We have seen that art and ideas about it are changing with every generation. The changes in paradigm and methods always bring new perspectives and ways of study. The aim of this article was not to present another "true picture of historical reality"; my objective was to propose one of the possible perspectives of conceiving sixteenth-century Mexican monastic architecture and art and contributing to the discussion about the nature of colonial art and its functioning. Thus, from the perspective of symbolical anthropology, my research has shown that:

1) the existence of two social modalities (structure and communitas) together with liminal areas, such as atriums, allowed the Indians the transition from one social status to another and hence incorporation into the early colonial society;

2) the fact, that the Republic of Spaniards represented the structure (it was a hierarchical society with the access to power and to the sacred) should legitimize its dominant position and motivate the natives to go through the liminal phase and a set of rites of passages (like baptism or marriage);

3) the communitas and liminality are temporary, for this reason they are associated with the regular and not the secular clergy;

DOI: 10.2478/eas-2018-0011 @ University of SS. Cyril and Methodius in Trnava. All rights reserved. 
MONIKA BRENIŠÍNOVÁ

Sixteenth-century Mexican Monasteries and Art. An Anthropological Perspective

4) despite the deeply religious character of the evangelization task, the mission to Christianize the natives has among other clearly political objectives - to legitimize the conquest of Mexico and to incorporate its inhabitants peacefully into Occidental society.

In brief, the fact that Indian society found itself after the arrival of Spaniards without access to power and the sacred was a strong motivation both on the individual and collective level to reject the old structures in form of pre-Columbian religious cults along with its system of values and beliefs and to accept new ones in the form of the Christian faith, as well as the standards, values and style of life of Western society embodied in monastic art and architecture. Mexican convents with their artistic decoration introduced the natives to the Christian worldview, showed them how to live in the new social arrangement and thus played a significant role in the process of conquest and colonization of the New Spain.

\section{Acknowledgements}

This article was written with the support of the European Regional Development FundProject "Creativity and Adaptability as Conditions of the Success in an Interrelated World", No. CZ.02.1.01/0.0/0.0/16_019/0000734. It is based on the research I undertook in Mexico in 2013 with the support of the Mexican Government Scholarship for International Students.

\section{Bibliography}

ANGULO, Diego - DORTA, Enrique Marco - BUSCHIAZZO, María José (eds.) (1950): Historia del arte hispanoamericano. 3 vols., Barcelona: Salvat Editorial.

ARACIL VARÓN, María Beatriz (1999): El teatro evangelizador: sociedad, cultura e ideología en la Nueva España del siglo XVI. Roma: Bulzoni.

ARIMURA, Rie (2008): Hacia una nueva historia del arte: desmitificación de los conceptos estilísticos del arte novohispano del siglo XVI. In Hispánica 52, pp. 165-183.

ARRÓNIZ BÁEZ, Othón (1979): Teatro de evangelización en Nueva España. México: UNAM.

ARTIGAS, Juan Benito (1979): La piel de la arquitectura: murals de Santa María Xoxoteco. México D.F.: Universidad Autónoma de México. 
MONIKA BRENIŠÍNOVÁ

Sixteenth-century Mexican Monasteries and Art. An Anthropological Perspective

BAILEY, Gauvin Alexander (2005): Art of colonial Latin America. London: Phaidon Press.

BALLESTEROS GARCÍA, Víctor Manuel (2000): Los conventos del estado de Hidalgo. Expresiones religiosas del arte y la cultura del siglo XVI. Pachuca: Universidad Autónoma del Estado de Hidalgo.

BALLESTEROS GARCÍA, Víctor Manuel (1999): Pintura mural del convent de Actopán. Pachuca: Universidad Autónoma del Estado de Hidalgo.

BAYÓN, Damián Carlos (1974): América Latina en sus Artes. París: UNESCO.

BAXTER, Sylvester - TOUSSAINT, Manuel - MARISCAL, Federico (eds.) (1934): La arquitectura hispano-colonial en México. México: Departamento de Bellas Artes.

BERNAL, Ignacio et al. (2009): Historia general de México. México: El Colegio de México.

BORGES, Pedro (1992): Religiosos en Hispanoamérica. Madrid: Editorial MAPFRE.

BRENIŠíNOVÁ, Monika (2017): Del convento al hombre. El significado de la arquitectura conventual y su arte en la Nueva España del siglo XVI (Ph.D. thesis). Prague: Universidad Carolina.

BURKE, Peter (2001): Eyewitnessing: the Uses of Images as Historical Evidence. Ithaca: Cornell University Press.

BURKHART, Louise M. (1992): Flowery Heaven: The Aesthetic of Paradise in Nahuatl Devotional Literature. In Res 21, Chicago: The University of Chicago Press.

CARRASCO, Davíd (1998): Náboženství Mezoameriky. Kosmovize a obřadní centra. Praha: Prostor.

CHAUNU, Pierre (1969): Conquête et exploitation des nouveaux mondes, XVIe siècle. Paris: Presse universitaire de France.

CLENDINNEN, Inga (1991): Aztecs: an Interpretation. Cambridge (Mass.): Cambridge University Press.

CLENDINNEN, Inga (2010): The Cost of Courage in Aztec Eociety: Essays on Mesoamerican Society and Culture. New York: Cambridge University Press.

CÓMEZ RAMOS, Rafael (1989): Arquitectura y feudalismo en México. Los comienzos del arte novohispno en el siglo XVI. México D.F.: Universidad Nacional Autónoma de México.

DURÁN, Diego (1967): Historia de las Indias. Vol. I. México: Porrúa. 
MONIKA BRENIŠÍNOVÁ

Sixteenth-century Mexican Monasteries and Art. An Anthropological Perspective

DUVERGER, Christian (2003): Agua y fuego. Arte sacro indígena de México en el siglo $X V I$. México D.F.: Landucci.

ESCALANTE GONZALBO, Pablo (ed.) (2008): El arte cristiano-indígena del siglo XVI novohispano y sus modelos europeos. Cuernavaca: Centro de Investigación y Docencia en Humanidades del Estado de Morelos.

ESPINOSA SPÍNOLA, Gloria (1999): Arquitectura de la conversión y evangelización en la Nueva España durante el siglo XVI. Almería: Universidad Almería.

ESTRADA DEL GERLERO, Elena (1978): Los temas escatológicos en la pintura mural novohispana del siglo XVI. In Traza y baza 71/88, Barcelona: Universidad de Barcelona.

ESTRADA DEL GERLERO, Elena (2011): Muros, sargas y papeles: imagen de lo sagrado y lo profano en el arte novohispano del siglo XVI. México: UNAM - IEE.

FRIEDEL, David - SCHELE, Linda - PARKER, Joy (eds.) (1993): Maya Cosmos, Three Thousand Years on the Shaman's Path. New York: Quill William Morrow.

GENDROP, Paul (1977): Diccionario de arquitectura mesoamericana. México: Editorial Trillas.

GENNEP, Arnold van (2008): Los ritos de paso. Madrid: Alianza Editorial.

GEERTZ, Clifford (2003): La interpretación de las culturas. Barcelona: Gedisa.

GIBSON, Charles (2012): Los Aztecas bajo el dominio español (1519-1810). México: Siglo Veintiuno Editorial.

GÓMEZ CANEDO, Lino (1993): Evangelización, cultura y promoción social. México: Porrúa.

GÓMEZ CANEDO, Lino (1977): Evangelización y conquista. Experiencia franciscana en Hispanoamérica. México: Porrúa.

GÓMEZ MARTÍNEZ, Javier (1997): Fortalezas mendicantes: claves y procesos en los conventos novohispanos del siglo XVI. México D.F.: Universidad Iberoamericana.

GONZÁLEZ SÁNCHEZ, Carlos Alberto (2011): New World Literacy: Writing and Culture Across the Atlantic, 1500-1700. Lewisburg: Bucknell University Press.

GONZÁLEZ TORRES, Yólotl (1995): Diccionario de mitología y religión de Mesoamérica. México: México: Editorial Larousse.

GRUZINSKI, Serge (2013): La colonización de lo imaginario. Sociedades indígenas y occidentalización en el México español, México: Fondo de Cultura Económica.

GRUZINSKI, Serge (2006): La guerra de las imágenes. De Cristóbal Colón a "Blade Runner" (1492-2019). México D.F.: Fondo de Cultura Económica.

DOI: 10.2478/eas-2018-0011 C University of SS. Cyril and Methodius in Trnava. All rights reserved. 
MONIKA BRENIŠÍNOVÁ

Sixteenth-century Mexican Monasteries and Art. An Anthropological Perspective

GRUZINSKI, Serge (1992): Painting the Conquest. The Mexican Indians and the European Reaissance. Paris: Flammarion.

KIRCHHOFF, Paul (1943): Mesoamérica: sus límites geográficos, composición étnica, y carácteres culturales. In Acta Americana 1, México.

KOBAYASHI, José María (1996): La educación como conquista. Empresa franciscana en México. México: El Colegio de México.

KUBLER, George (2012): Arquitectura mexicana del siglo XVI. México: Fondo de Cultura Económica.

LEÓN-PORTILLA, Miguel (ed.) (2013): Visión de los vencidos: relaciones indígenas de la conquista. México: FCE.

LOCKHART, James (2013): Los nahuas después de la conquista. Historia social y cultural de los indios del México central, del siglo XVI al XVIII. México D.F.: Fondo de Cultura Económica.

LYNN, Kimberly (2013): Between Court and Confessional: The Politics of Spanish Inquisitors. Cambridge: Cambridge University Press.

MCANDREW, John (1965): The Open-Air Churches of Sixteenth-Century Mexico. Atrios, Posas, Open Chapels, and Other Studies. Cambridge (Mass.): Cambridge University Press.

MELI PIRALLA, Roberto (2011): Los conventos mexicanos del siglo XVI: construcción, ingeniería estructural y conservación. México D.F.: Porrúa.

MORENO VILLA, José (1986): La escultura colonial Mexicana. México: Fondo de Cultura económica.

PARDO, Osvaldo F. (2004): The Origins of Mexican Catholicism: Nahua Rituals and Christian Sacraments. Ann Arbor: University of Michigan Press.

PARTIDA, Armando (1992): Teatro de evangelización en náhuatl. México: CONACULTA.

PHILLIPS, Richard E. (1999): La participación de los indágenas en las procesiones por los claustros del siglo XVI en México. In Relaciones 20/78, México: El Colegio de Michoacán, pp. 225-250.

PRESCOTT, William Hickling (2001): History of the Conquest of Mexico. New York: Modern Library.

RENIER, Gustaaf J. (1950): History, its Purpose and Method. London: Allen \&Unwin. 
MONIKA BRENIŠÍNOVÁ

Sixteenth-century Mexican Monasteries and Art. An Anthropological Perspective

REVILLA, Manuel G. (1893): El arte en México en la época antigua y durante el gobierno virreinal. México.

REYES-VALERIO, Constantino (2000): Arte indocristiano, México: Instituto Nacional de Antropología e Historia.

ROMERO DE TERREROS, Manuel (1922): Historia sintética del arte colonial de México: 1521-1821. México: Porrúa.

RUBIAL GARCÍA, Antonio (2012): La evangelización de Mesoamérica. México: Consejo Nacional para la Cultura y las Artes.

STEN, María - GARCÍA, Oscar Armando - ORTIZ BULLÉ GOYRI, Alejandro (2000): El teatro franciscano en la Nueva España: fuentes y ensayos para el estudio del teatro de evangelización en el siglo XVI. México: UNAM.

SCHUESSLER, Michael Karl (2014): Foundational Arts: Mural Painting and Missionary Theater in New Spain. Tucson (Ariz.): University of Arizona Press.

TORRE, Miguel A. de la (ed.) (2009): Hispanic American Religious Cultures. Santa Barbara (California): ABC-CLIO.

TOUSSAINT, Manuel (1965a): Arte colonial en México. México: UNAM.

TOUSSAINT, Manuel (1965b): Pintura colonial en México. México: UNAM.

TOUSSAINT, Manuel (1962): Paseos colonials. México: UNAM.

TURNER, Victor (1982): From Ritual to Theatre: the Human Seriousness of Play. New York: PAJ Publications.

TURNER, Victor (1969): The Ritual Process: Structure and Anti-Structure. Chicago: Aldine. Pub. Co.

VARGAS LUGO, Elisa (2005): Imágenes de los naturales en el arte de la Nueva España siglos XVI al XVIII. México: Fomento Cultural Banamex.

VERGARA HERNÁNDEZ, Arturo (2008): El infierno en la pintura mural agustina del siglo XVI. Actopan y Xoxoteco en el Estado de Hidalgo. Pachuca: Universidad Autónoma del Estado de Hidalgo.

WILCOX, Melissa M. (2013): Religion in Today's World: Global Issues. Sociological Perspectives. London: Routledge.

WRIGHT, David (1998): Los franciscanos y su labor educativa en la Nueva España (1523-1580). México: INAH. 